Jerome Ikechukwu

Okonkwo

\title{
Folks-media and the new era of evangelization: The Igbo perspective
}

\section{Introduction}

Since the "Second Vatican Council", the issues of the media in the process of evangelization have been of paramount concern. The church all over the world has been called upon to consider the processes of the media of information and communication, within the reach of their locations, as serious chances for the spread of the gospel message as well as possible dangers and or impediments to the same process. Mass communication as a phenomenon of our time, has reached such levels of complication. Pope John Paul II., in his "Redemptoris Missio", (cf. "Centesimus Annus"), ${ }^{2}$ expresses this level of mass media complication in the world of today as the first "Areopagus" of our time. The reasons for this "Areopagus Syndrome" is the after-effects of the "Global Village Syndrome" whose import is the break-through of all possible boundaries in time and space. The mass media have broken the boundaries of:

"... inter alia, political, cultural, linguistic, socio-economic and sociopsychological identities ... embracing, collecting and connecting nationalities and peoples, languages and cultures." 3 Issues like "cultural industry", "media imperialism", "pressure power", "media manipulation" etc. are consequences of the above disposition of the mass media of our time. A UNESCO report in this context says:

"The mass media that have become one of the basic supports of cultural dissemination transmit messages that are not culturally neutral. They reflect the thinking, the ideas, the values, in short, the vision of the world of those who use them. When they serve as the channel for transmitting to a given region value systems or ways of life which are foreign to the people of that region, they cannot be prevented in the end from wiping out the specific values of those peoples, thus becoming, even if unintentionally, instruments of cultural alienation ... The important thing, no

1 Verlautbarungen des Apostolischen Stuhls (100) (1990): Redemptoris Missio: Über die Fortdauernde Gultigkeit des Missionarischen Auftrages, Art 37c.

Cf. John Paul 11, Centesimus Annus, Art.12ff; in AAS, LXXXIII(1991) P.807.821.

Cf. Adorno,T.W.:Television and the Pattern of Mass Culture; In Schramm, W. (ed.) (1960): Mass Communication,Urbana,111: University of Illinois; cf. Okonkwo, J. (1986): The History and Some Problems of Television Service in Anambra State of Nigeria: A Review of Televison Technology in the Context of a Developing Country (cover page remarks). 
doubt, is to recognise this fact and to seek ways of safe-guarding the cultural identity of each people without jeopardising the necessary continuation of exchanges among different cultural areas, or the indispensable mutual enrichment of cultures, since it is also important, for the life and development of each culture, to avoid the other extreme, that is to say the isolation which can also be harmful."4

The church on her part, as the community of God's people in the world, (Sic tu me misisti in mundum, et ego misi eos in mundum (Joh.17:18)), cannot be isolated from the experiences of the world's changes, crisis and anguish. The church is supposed, in this disposition, to be a sign of hope in the seasons of expectations. ${ }^{5}$

Since the publications of "Inter Mirifica" and "Communio et Progressio", we have noted the consciousness of the church in mass media matters, especially in issues concerning the concepts of mass culture, media generation, signs of the time, new language, information community etc. Consequently, that is to say, in the light of the mandate of the church from her master to bring the good news to the ends of this world (Mt.28:18-20), it is therefore obvious, that all concerned in this proclamation have to face the challenges of the new currents of development in the light of faith. It is part of the vocation of the church to extend the gospel message to all the dimensions of the mass media forms and technology. This is in line with the plan of God in the order of creation. ${ }^{6}$ The church cannot bracket herself out of the currents of mass media events of her time or else she would find herself guilty of irresponsibility to the mandate of her master. Her missionary visions must be extended to those media that have such powers in the fashionable models of human "habitus" and understanding today. ${ }^{7}$

The missionary mandate of the church, on the other hand, recognises no boundaries just like the mass media information dissemination today. ${ }^{8}$

4 UNESCO (1982): Cultural Industries: A Challenge for the Future of Culture, Paris, Unseco Press, p. 12.

5 Verlautbarungen des Apostolischen Stuhls (37) (1981): Entwicklung der Pastoral geistlicher Berufungen in den Ortskirchen: Erfahrungen aus der Vergangenheit und Plăne fuir die Zukunft, Art. 3.

6 Aetatis Novae (1992): Arbeitshilfe (98): Pastoralinstruktion zur sozialen Kommunikation zwanzig Jahre nach Communicatio et Progressio, Art. 3.

7 Paul VI. (1975): Apostolisches Schreiben "Evangelii Nuntiandi" an den Episkopat, den Klerus and alle Gläubigen der Katholischen Kirche über die Evangelisierung in der Welt von heute, Art.45.

8 Verlautbarungen des Apostolischen Stuhls (100): Redemptoris Missio (1990): Über die fortdauernde Gültigkeit des Missionarischen Auftrages, Art. 37; "Die Mission ad gentes kennt kraft des weltumspannenden Auftrages Christi keine Grenzen." 
The fact in this context is that the gospel of Christ, "must" also break all bounds and boundaries of cultural, political, socio-economic, socio-linguistic, ecological and socio-psychological etc. heritages and identities. The evangelization mandate imbued in the commanding words of $\mathrm{Mt}$ 28:18.20 - "teach - 'docete' and all nations - 'omnes gentes'", guarantee the extensive possibilities of the "Sache Jesu"9 to have also a global trans-continental and trans-national inter-flux, embracing, collecting and connecting nationalities and peoples involved and confronted, - all kinds of habitual linguistic and cultural differentiation $\mathrm{s}^{10}$ not withstanding.

The church in the present age is very much conscious of the dangers involved in her mission "ad gentes". In the pastoral instruction "Aetatis Novae" on the social communication media -twenty years after "Communicatio et Progressio", the church underlines her priorities and possible chances and or challenges in the face of the present day usage of mass media in the process of evangelization. The first among the list of the priorities is the protection of the human culture. The church declares in this regard as follows:

“... Often, too, for the sake of evangelization and catechesis the Church must take steps to preserve and promote folk media and other traditional forms of expression, recognizing that in particular societies these can be more effective than newer media in spreading the Gospel because they make possible greater personal participation and reach deeper levels of human feeling and motivation. The overwhelming presence of mass media in the contemporary world by no means detracts from the importance of alternative media which are open to people's involvement and allow them to be active in production and even in designing the process of communications itself. Then, too, grassroots and traditional media not only provide an important forum for local cultural expression but develop competence for active participation in shaping and using mass media. "11

This position of the church cited above, stands as the reason for this paper. The church recognises the importance of the folks-media. The status of these media in the identification of the peoples' identity and heritage is of paramount importance if an effective evangelization is proposed in the areas in question. To separate such media from the processes for the spread of the good news would mean to work without the culture. The major issue here is that it is not the intention of the gospel

9 Marzsen, W. (undated): Die Sache Jesu Geht Weiter, Aachen.

10 Okonkwo, J. (ed.) (1994): The church as "Community Media": the Import of the Theology of Communication; In: Pastoral Management and Communication, Enugu, p. 12.

11 Aetatis Novae, op. cit., Art. 16. 
mandate to effect any Christian transformation without the incumbent culture. 12

According to Kraft:

"The task of Christianity vis-a-vis any given culture or subculture is primarily the transformation of the conceptual system (world-view) of that culture. Such transformation is accomplished by bringing Christian understandings of supracultural truth to bear on the worldview of the culture."13

From the above positions, we have in a way established the direction of this paper. The aim of this paper is to take the position of the church as stated above very seriously and discern the challenges and chances and the friction points of Christianity in a given cultural heritage like that of the Igbo. But before we do this, we find it as very necessary to state "The little worry" of this paper.

\section{The little worry}

The little worry of this paper stems from the fact that for the past (ten) years the church has been so much concerned with express instructions and pastoral directions about the effects and affects of the modern media. Little or no official instructions have been given to the traditional media and or folks-media.

In view of the above statement, a short review of the most recent pastoral instructions will justify the issue (the little worry) in this section of this paper.

On 31st May 1987, ie. on the 21st. "World Social Communication Day", Pope John Paul II. directed his instructions towards the communication strategies as means towards the services of Justice and Peace in the world mission of Christ. The media of social communications were advised to be more sensitive about national and international Peace and stability. The media should not operate as the "mission or idea of the stronger". The media should serve as instruments to break the barriers of politics, class, race and culture discriminations and guarantee what the pope calls "total dialogue". The "technical wonder" must be seen as a gift of God for the feature and the propagation of Justice and Peace. ${ }^{14}$

12 Kraft, C. (1979): Christianity in Cultre: A Study in Dynamic Biblical Theologizing in Cross - Cultural Perspective, New York, p. 345.

13 Ibid., p. 349.

14 Cf. The message of the Pope on the 21st. world social communication day, 31st. May 1987. 
On the 22nd "World Social Communication Day", 15th. May 1988, the attention was again on the electronic media in the service of human solidarity and collective life. The electronic media should not be agents of fear. As a Marian Year message, the Pope instructed all media practitioners to see these instruments as part of the "signs of the time" for the diffusion of tension among peoples and nations. This in his view will help create an ethic of brotherhood and tendency of hope for a world of mutual respect, human rights, dialogue, justice, unity, solidarity etc. 15

In 1989 the emphasis was on the chances of religious education through the Newspapers, television and radio. This document made little or no mention of the folks-media in the theme. The major concern in this instruction was to underline the dangers of "secularisation" of religious values within the currents of media information, especially in the industrialised part of the world. The question was about how these media can effectively advance the process of evangelization to the modern man and inspire and or assist him accept the gospel message in such a way that this message would penetrate into today's life style. The bone of contention was on the quality of production. ${ }^{16}$

The message of 1990 was directed towards the possibilities of what the Pope called "Computer Culture" in the process of evangelization. The direction of the worry was towards the fruit of "Informatic" technology today. The appeal was to utilise positively and control the inter-flux of the computer culture and language in the context of a promising growing world for the youth. 17

In the message of 1992, a general and collective approach was given to the mass media (more emphasis on the electronic and Print media) as regards their break-through into the modern market square of open ideas of information exchange. The Pope within this general concern, did not bracket any information medium out. He recognised all as the gift of God for the work of God. Despite the fact that no type of information medium in this context was left out of this concern, still (our little worry) the major occupation was in favour of the catholic international organisations for films and cinema (OCIC), the catholic press (UCIP) and the catholic radio and television (Unda). To this effect the Supreme Pontiff appealed to all Bishops' conferences and religious organisations to make sure that

15 Cf. The message of the Pope on the $22 \mathrm{nd}$. world social communication day, 15 th. May 1988.

16 Cf. The Message of the Pope on the 23rd. World social communication day, 7th. May 1989.

17 Cf. The Message of the Pope on the 24th. World social communication day, 27th. May 1990. 
their missionary mandate is felt in all the available social communications media (new languages) in their areas. 18

The 1993 address needs no extra commentary because the reference was on culture and conscience in the use of video and audio cassettes. These areas of the "new language and culture" may not be left out of the unchanging truth of the gospel. The parents are called upon to this responsibility of critical examination of the media world of the video and audio cassettes for the explicit protection of the family and society. 19

The focus in 1994 was on the family and television exposure. The problems of pornography, eroticism, brutality, moral relativism and religious scepticism were underlined as dangerous effects of media manipulation. To this effect, Christians and the Bishops' conferences should work out a pastoral plan to protect the family dimensions. ${ }^{20}$

In 1995 cinema took up once more the option. The cinema industry was seen as the vehicle for the transport of cultural values. Cinema is known for it's language in inter-cultural dialogue in view of a general conception of the "Bonum Commune". Cinema is the melting pot of arts and culture. ${ }^{21}$

The last example (to our little worry) is the message of the Pope on the world social communication day of 1996 . The appeal was centred on the media for the promotion of the role of the woman; emancipation and social equality for the service of what the Pope calls the "civilisation of love" in which the woman is privileged and specially qualified. Special mention was made about the press, cinema, radio, television, the music industry and computer net-work in the processes of woman's exploitation. The appeal is to use these media towards a respectful projection of the woman "Genius".22

What we have tried to do so far is to under-score the fact that little concern has been given to the possibilities of the folks-media in the process of the propagation of faith. This is the core of our "little worry". If you do not say "I am" it is very difficult for the other to say "you are".

For this very reason, it should be considered here as most necessary to

18 Cf. The Message of the Pope on the 26th. World social communication day, 31st. May 1992.

$19 \mathrm{Cf}$. The Message of the Pope on the 27th. World social communication day, 23rd. May 1993.

20 Cf. The Message of the Pope on the 28th World social communication day, 15th. May 1994.

21 Cf. The message of the Pope on the 29th. World social communication day, 28 th. May 1995.

22 Cf. The message of the Pope on the 30th World social communication day, 19th. May 1996. 
pin-point the reaction of the African Synod of Bishops "Ecclesia in Afri-

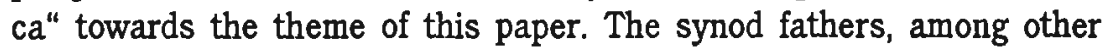
facts, noted the urgency to promote and respect the folks-media. The African church must be seriously concerned about the use of these local media in the process of the propagation of faith in their localities. There must be a more serious involvement of the local church in the conscious use of these media "ad intra and ad extra" in the promotion of the word of God. ${ }^{23}$

These folks-media, as we shall see later, are carriers of the wisdom of the people and their spirit. They are the transmitters of what the Germans call "Volksweisheit and Volksgeist". Having said this, it becomes an urgent task to underline, in major terms, the issues strictly involved in our little worry as follows:

The truth of the fact remains that about $70 \%$ of the population of the Christians in the mission churches are still living with these folks-media. These folks-media form and translate their day to day real presence in their real world.

As we have said above, the major concern of evangelization is the transformation of the people by means of the transformation of their conceptual world-view systems. The best method of doing this is the "Areopagus" frame of reference:

"Men of Athens! I see that in every way you are religious. For as I walked through your city and looked at the places where you worship, I found also an alter on which is written, 'To an Unknown God'. That whith you worship, then, even though you do not know it, is what I now proclaim to you" (Acts 17:22-23).

When we talk about an "Areopagus frame of reference", we want to understand here the incumbent theological missionary methods and ventures (including the media services) that have to be etic in their perspectives in such a way as to be very sincerely flexible and adaptive to the emic realities of the locality in question. When we fail to develop this frame of reference with respect to the people to whom we want to communicate the gospel message, we shall be doing no justice to the missionary mandate of Christ especially when we cling to theological methods appropriate in the missionaries' culture (in our case the European culture) in preference to equally valid and even much more relevant local expressions through which the mission land and people have the glimpse of the absolute Truth. 24

23 Verlautbarungen des Apostolischen Stuhls (123): Ecclesia in Africa (1995), Art. 122ff; cf. Propositio, 57ff.

24 Cf. ibid., p. 301. 
In this paper, therefore, the said "Areopagus frame of reference" presents our little worry. This stands to say that:

"To relate the (gospel) message to the real life of one's hearers, the communicator (Pastor) must learn to employ the communication devices familiar to the receptor in ways to which the receptor is responsive. Credible messages start from where the receptor is. In many cultures this involves the knowledge and use of a variety of proverbs, aphorisms, and tales of various kinds. Such literary devices form important vehicles within their communicational system." 25

What we have tried to say here is that the gospel message should have a cultural validity or else this message cannot transform the hearers. If this message is not disseminated through the media of the people, that is, "through the press of the people", it will be difficult to convert the hearers of the word. The instructions on the means of social communication "Communio et Progressio" supports our little worry by saying that Christ while on earth revealed Himself as the Perfect Communicatior. Through His 'Incarnation', Christ utterly identified. ${ }^{26}$ Himself with those who were to receive His communication and gave His message not only in words but in the whole manner of His life. Christ spoke to His hearers from within their culture, that is to say, from out of the PRESS of the people. He preached His divine message by adjusting to His people's way of talking and to their patterns of thought and spoke out of the predicament of their time. ${ }^{27}$ This ascertains the cultural validity of the message of the gospel. This is to say that the gospel carefully evaluates a culture in terms of the cultural values and goals as to present the said culture with supracultural values and goals. In this manner, the gospel recognises the values set up by every society to guide the life of the people. It is, therefore, expected to stress the dignities inherent in every body of customs and conventions and by so doing brings into relief the validity of every set of norms for the peoples whose lives are guided by them, and the values these represent. 28

Areopagus frame of reference stands therefore as a missionary discipline that comes out of the respect for differences - and as mutual respect.29 This in our own view underlines a "Golden Rule" for the social communications in the process of evangelization for all times. In the line

25 Ibid., p. 161.

26 "He had compassion on them" (Mk 8,1-10; 6,32-44; Mt 15,32-39; Lk 9,10-17; Joh $6,1-13)$. This expression of compassion demonstrates the "Kenosis" in the message of the incarnation; cf. Phil 2,5-11.

27 Communio et Progressio, Art. 11.

28 Herskovits, M. (1948): Man and His Works, New York, p. 77.

29 Cf. ibid. 
of the said "Golden Rule" Ukah says "The word of God effectively communicated, helps the community to understand 'WHO THEY ARE and WHO OTHERS ARE' and also helps them to sort out their problems".30

It is true that cultures pattern perceptions of reality into certain conceptualisations of what reality can be and/or should be. The said reality guarantees what may be regarded by the people concerned as actual, impossible, possible and probable.

"These conceptualisations form what is termed the 'world-view' of the culture. The world-view is the central systematisation of conceptions of reality to which the members of the culture assent (largely unconscious) and from which stems their value system. The world-view lies at the very heart of culture, touching, interacting with, and strongly influencing every other aspect of the culture. The world-view of any given culture presumably originated in a series of agreements by the members of the original group concerning their perception of reality and how they should regard and react towards that reality." 31

Pope Paul VI. calls the rift between the gospel and the people's culture "the drama of our time". ${ }^{32}$ The meaning of this drama is that the gospel message takes an express note of the particular set of social arrangements of the people confronted as to be a sign of hope in their struggle with their world and existence. We know this fact from the issues of social sciences that man is not a passive victim of his world and physical environments. Man can act on his world and can also transform this, his world, to suit his ends in his process and occupation to give answers to his problems. Hodgen once argued as follows:

"The historically important thing in regard to natural resources is man's attitude towards them. It was not the availability of iron that created the Iron Age ..., nor the presence of coal that ushered in the Industrial Revolution, but the initiative of certain men at particular moments in time in finding a use for these mineral riches of the earth. The modifications or changes that have taken place in mechanical contrivances follow and tangibly employ prior modifications and changes in the purpose of human tool-makers and tool-users." 33

What we want to stress here is that any conscious project in the process of evangelization must consider the distinctive modal patterns of

30 Ukah, L. (1994): The Priest As An Effective Communicator; in: Okonkwo, J. (ed.):

Pastoral Management And Communication, Enugu, p. 36 (emphasis are mine).

31 Ibid., p. 53.

32 Evangelii Nuntiandi, Art. 20.

33 Hodgen, M. (1959): Change and History; Viking Fd. Publ. Anthrop., no. 18; cf. Krech, D. et.al. (1962): Individual In Society: A Textbook of Social Psychology, p. 342. 
behaviour and the underlying regulatory beliefs, norms and values of the people within the geography of this mission. This process takes into consideration the so-called explicit and implicit aspects of the given culture. The explicit implications are the statistical statements that "culture is as people do". What must be considered here are the standard behaviour events in standard interpersonal behaviour events -evangelization "ad extra" as said above. ${ }^{34}$

In the implicit conception, we mean to include the modal cognitions, interpersonal response traits, wants and the people's attitude in their society. This process involves a method of evangelization "ad intra" 35 reflecting and or transforming cultural beliefs, cultural values, cultural norms, and cultural premises.

"The implicit culture includes many premises about the world which remain unverbalised. These premises are tacit generalisations which may be thought of as 'the metaphysics of the people'. They are likely to be revealed only through the analytic work or intuitive speculation of the social observer who suspects that a set of seemingly unrelated actions is meaningfully patterned." 36

With this explanation, we can now go direct into the expositions of what we understand in this paper as "folks-media".

\section{The scope of folks-media}

One of the most classical illustrations of what the folks-media are all about was that of Professor Ugboajah in his work on culture and communication in West Africa in 1985. He told this story of the English Colonial Governor who once sat on the stool of the king of Ashanti in Ghana as a way to communicate his command and authority as the incorporated representative of the Queen of England. The concern of the Governor was to transplant the English conception of royalty and political power into their colony. He was unfortunately and perfectly ignorant of the explicit and implicit meanings of this stool for the Ashanti people. His English background and culture added to his fashion and fantasy of supremacy and superiority, exposed him to serious dangers because of his lack of integrative and/or interactive cross-cultural knowledge. This governor had no knowledge of either the connotative nor the denotative meanings of this Ashanti stool of rulership and kingship. This English man had no

34 Cf. Ecclesia in Africa, Art. 122.

35 Ibid.

36 Krech, D. et.al., op. cit., p. $352 f$. 
explicit identification of the stool as a "Referent" in the Ashanti culture. The Governor had no ideas about the wider penumbra of actions, feelings and tendencies that cluster about this stool. Convinced of his position and power he sat on the stool.

"But the significance of the stool in the mind of the people of Ashanti was reverence, as being not an appurtenance of the kingly office, but of an embodiment of the nation's soul. They were insulted. They were provoked. They went home and prepared for war." 37

The content of the action and/or reaction of the Ashanti people was as a result of the context of the meaning of this stool which has both verbal, non-verbal and more especially significance contexts. These social contexts were foreign to the "behavioural contexts" of the English Governor. The consequences of this cross - cultural "en pass" was the war. The social content of this stool is rooted in the cultural interpretations of what we have called in former research papers "Oramedia traditions", whose vehicles are the folks-media.

Since the Governor was not initiated and was also indisposed to be initiated, there was only the singular answer left to this cross-cultural contact, that is "Crisis".

It is very important to note that what we have called "Oramedia" are part of the total complex of what this paper presents now under folksmedia.

Folks-media can also be called community media. The scope and framework of folks-media are registered within the platform of the interplay of Igbo socio-facts which form indicators of and for interpersonal - response relations. These socio-facts may among other things include, story telling, music, dances, customs, feasts, myths and mythologies, agegroup unions, all kinds of oration, rite, institutions etc. The folks-media form the matrix for all social organs for social conduct, control, harmony, linguistic and or language signs and symbolism..$^{38}$

As we have pointed out above, folks-media can be associated to a large extent with the mass communication concept of "community media". Berrigan defines community media as:

"Adaptations of media for use by the community, for whatever purpose the community decides. They are media to which members of the community have access, for information, education, entertainment, when they want access. They are media in which the community participates, as

37 Ugboajah, F. (1985) (ed.): Oramedia in Africa, in: Mass Communication, Culture and Society in West Africa.

38 Okonkwo, J.:Oramedia - Traditions and the Igbo Question in Nigeria: A Philosophy of Identity, in: Gehlhaar, S. (ed.), Prima Philosophia, Cuxhaven - Dartford, p. 33-43. 
planners, producers, performers. They are the means of expression of community, rather than for the community. Community communications describe an exchange of views and news, not a transmission from one source to another." 39

The most important aspect of this concept is that it is community based. For this reason the folks-media and the community media share common features. Folks-media are ontologically grounded on indigenous and/or local culture. They have local cultural features and most often strictly and locally conventional. They are co-determined by social relationships and world-views. These co-determinants give them definitions, functions, use, rules and regulations, maintenance and respect of fellowship. 40

On defining the relationship between folks-media in Oramedia traditional systems, Ugboajah has this to say : Folks-media and/or Oramedia -

"... Have been described as being simple in form and generally available to all at no material cost. They are in the public domain and anonymous in origin. There might be little differentiation between their producers and their consumers. But they communicate directly through any of the senses via folksways. (They) are made up of dialogue and verbal exchange, a feature that is provided by almost constant presence of one or more surrounding listeners. They may be defined as functional and utilitarian. Their most important purpose is to provide teaching and initiation, with the object of imparting traditional aesthetic, historical, technical, social, ethical and religious values. They provide a legal code of sorts which rests on stories and proverbs generated through the spoken word. They also play other roles in the village society such as mobilising people's awareness of their own history, magnifying past events and evoking deeds of illustrious ancestors. Thus they tend to unite a people and give them cohesion by way of ideas and emotions." 41

From the above position we can underline the facts that the folksmedia are integral parts of oral traditions and are totally rooted in the people. For these reasons, the folks-media command what may be called "participatio auctuosa". On the grounds of the above, the community has a frame of reference bound up in their social world-view.

The UNESCO conference on communications in Africa in Cameroon (1980) identified the urgent need to re-integrate and or revive the folksmedia in Africa.

39 Berrigan, F. (1979): Community Communications: The Role of Community Media in Development, UNESC0 Paris, p. 8.

40 Ugboajah, F., op. cit., p. 166.

41 Ibid, p. 167. 
This conference states as follows:

SOURCES AND FIELDS OF IGBO FOLKS-MEDIA

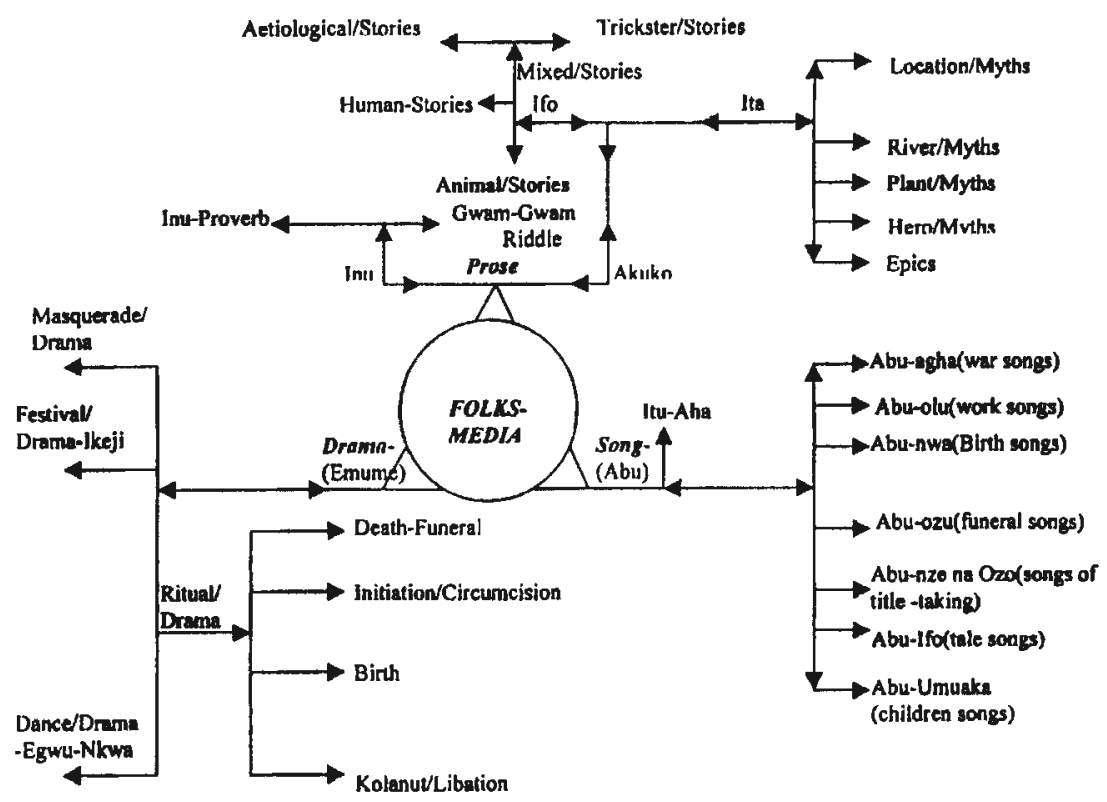

THIS SKETCH SHOWS THE CULTURAL INTER-PLAY OF THE FOLKS-MEDIA AND THE POSSIBLE PLATFORM OF ORAL SELECTION FOR AN AUTHENTIC MISSIONARY COMPETENCE AND PERFORMANCE (eg. Sermans and or Preaching of the Word)(Cf. Chatwu, H.(1994) : Igbo Oral Lilerarure : Theory and Tradition, Abak, p. 47)

"They ... create in most general terms the images and myths of the world of the members. (They) are not foreign since they are made by the people for themselves out of the matrix of their cultural values proven through generations. They provide an immense functional framework for artistic creation and also the vehicle and traffic for the dissemination of identity, culture, roles and information necessary for day-to-day struggle for social survival ... They are seen and respected as the soul of social integration, competence and identity. They are the interpersonal media speaking the language, the idioms and 'Weltanschuung' of the people. They are known and proven through interactive performance." 42

42 Okonkwo, J.: Oramedia, op. cit., p. 35; cf. UNESCO (1980) Intergovernmental Conference on Communication Policies in Africa, Paris, p. 22. 
From the above considerations, we can conclude this section by emphasising the fact that the folks-media (as community media) and Oramedia traditions are related and interwoven in their concrete social symbolism. The symbols within their operational fields of competence and performance give content, meaning social weight and communal consciousness. In this context we can call the folks-media "the practical book of history" of the people for the people. And to understand the people involved and/or interact with them in manners of media transfer or through the process of propagation of the gospel message, the one under this "missio cannonica" (eg. a Missionary) is expected to respect and appreciate this "book of history" as a pre-condition to success in the evangelization process.

\section{The mission church and the conflicts in cross-cultural evangelizati- on: external problems}

The history of the church on the African continent is as old as Christendom as such. Christianity from every historical dictation can be identified as one of the traditional African religions. It is even a statement of fact to note that Christianity is older in the African continent than the Christian history of western Europe. The Coptic church traces her foundations on the foot-prints of the Apostle St. Mark. We understand that during the apostolic age, Christianity had a strong hold in the parts of North Africa down to Ethiopia, Sudan and even some sections of central Africa. It was the spread of Islam that almost stopped the expansion of the gospel message to the other parts of Africa especially towards the west and south of this continent. 43

In the case of this paper, the actual evangelization of the section of this case-study (Igboland) - West Africa, started with the return of the west African slaves. ${ }^{44}$

During this period of the return of the west African slaves, the interest of the European Missionaries, Colonial Adventurers and Traders increased.

As regards the catholic missionary adventures in Igboland, we have to first of all underline the conflict that marked the "Begin" of the spread of

43 Mbiti, J. (1974): Afrikanische Religion und Weltanschauung, Berlin, p. 1; 296ff.

44 In 1787, 377 slaves came back to west Africa; in 1792 about 1200; in 1800550 came back and by 1805 a total of about 40,000 came back; cf. Okonkwo, J.: Die Situation der Kirche in Nigeria. Eine kritische Überlegung, Gastvortrag - Phil.-Theol. Hochschule St. P8lten, p. 13. 
the catholic doctrine in this area of our case-study. It is very sad to note that the first catholic missionaries arrived in the historic Igbo heartland (Onitsha) in the same year as the Berlin Conference. The African historical associations with this conference is in concrete terms, the "tearing of Africa into European political pieces". After this conference, part of the booty captured by Britain was, until 1960 (Nigerian Independence), this section of the African continent still called Nigeria. We have noted in a research paper issues involved in this type of cross-cultural political manoeuvre. We said as follows:

"When the British came to the country, they saw that the various peoples of their new territory, each inhabiting mainly a particular geographical area, did not have a common administration, and that they spoke different languages. For administrative convenience and commercial purposes, they decided to unite all these peoples together under one administration. They maintained among other things, law and order over the whole country and superimposed a new language system over the traditional ones." 45

The major problem imbued in this interplay of colonialism and the missionary occupation was that there was a psycho-social conflict in minds of the people of the colonial-mission land. It was difficult to distinguish between the intentions of these European visitors. The question was: Who was preaching "Christ and who was preaching Capital and or Cash?" This psycho-social conflict is underlined in the fact that these visitors came from the same "European Brotherhood" - the missionary cum colonial officer. ${ }^{46}$

An example of this psycho-social conflict among the Igbo missionchurch was this story of the missionary in Onitsha who attempted the conversion of a traditional ruler. The story was that this Bishop wanted to baptise this old man on his death-bed. This traditional title holder expressed his readiness to receive this baptism and asked the minister this simple question: Will this ritual (baptism) prevent me from joining my ancestors after my death? And the missionary's answer, out of his European cultural make-up, was YES!. Consequently the old man refused his baptism. This is another extreme of the Ashanti story told above. One of the most important missionary of Igboland "Rev. Fr. Lutz" has been reported to have advised that any missionary who gets ready to go to

45 Okonkwo, J. (1994): Nationalism and Nationism: The Sociolinguistic Cross-road of the Nigerian National Language Policy, in: AAP (40) 115-130.

46 Mbiti, J., op. cit., p. 296, noted this popular proverb among Africans in this issue which states "einen römisch-katholischen Priester und einen Europäer gibt es nicht". 
Africa must be fully convinced about the fact that this "Dark Continent" is a cursed land and is entirely engulfed by the power of the devil. ${ }^{47}$ Africa has been called by the missionaries of the "Mission Church" as the "Citadel of Paganism" and the missionaries of the time praised their work and achievements as a war through which the "Lord of Hell" had his possessions hotly contested, especially during the missions of $1908 .{ }^{48}$ This is the missionary ideology of "dominance" which sees any other culture that is not European as radically inferior. On this issue of missionary dominance, Uzukwu says:

"Confirmation of this dominance came from fantastic stories peddled around by travellers and missionaries, and the selective way in which missionaries presented Africa to the Western world, especially when it comes to raising funds. The value of African cultural values were glossed over." 49

When we consider the present reaction of the 2nd Vatican church on this issue of the ancestors, we still discover that the conflict is not yet over. The African theology has no problem in understanding the position of the ancestors within the doctrine of "Communio Sanctorum". The African Synod Fathers (Ecclesia in Africa) presented this aspect of their religious foundations and spirituality so that Rome may take a stand on this African reality. But one notes the conflict of Rome in this matter. Instead of taking a doctrinal stand on this issue, the Pope concludes by returning the issue with an open-end question. I personally and sincerely don't know who is expected to give the answer. ${ }^{50}$

From the above point of view, it becomes urgent to introduce another source of psycho-social conflict which has also until now mounted serious hurdles on missionary ventures.

Just as we have historically underlined above, with regard to the political tear of the African continent through the colonial powers, there is also an equivalent tear in Christian religious matters. It is important to note that the missionaries also rushed Igboland from different cultural mi-

47 Isichei, E. (1970): "Seven Varieties of Ambiguity: Some Patterns of Igbop Response to Christian Missiona", in: Journal of Religion in Africa (3), p. 120.

48 Jordan, P. (1949): Bishop Shanahan of Southem Nigeria, Dublin, p. 44.

49 Uzukwu, E. (1988): Missiology Today: The African Situiation, in: Religion and African Culture - Inculturation. A Nigeria Perspective, Enugu, p. 148.

50 Ecclesia in Africa, Art. 43: "Die Söhne und Töchter Afrikas lieben das Leben. Gerade diese Liebe zum Leben läßt sie der Verehrung der Vorfahren so große Bedeutung beimessen. Sie glauben instinktiv, daß jene Toten weiterleben und in Gemeinschaft mit ihnen bleiben. Ist das nicht irgendwie eine Vorbereitung auf den Glauben an die Gemeinschaft der Heiligen?" 
lieux, backgrounds, mentalities, confessional and doctrinal distinctions. To this effect, there is no unity in the confessional appreciations of the Igbo cultural values within some of the folks-media systems. Some mission churches admit for example, traditional titled men and women (Nze na Ozo ) into their church leadership and/or membership, while others condemn the same and some are yet to do so. As a result of this, there is no common religious ontology and/or religious language. In a little Igbo town of Okigwe in Imo State, (ca. 7000 inhabitants), about 61 different denominations propagate the same Christian gospel message. ${ }^{51}$

This fragmentation of Christianity carries within itself also the fragmentation of the "cultura Christi" because of the incumbent fragmentation of the "cultura ingenii" and "cultura animi" of the people.

It is moreover important in this section to point out that the "Founding Fathers" of the mission churches had little or no interest in appreciating the principles of Igbo traditional faith on the Great God "Chukwu - Chineke - Ezechitoke", spirituality and religious symbolism and language. We want to note it here as most unfortunate, that these founding fathers of the mission churches exposed (through their missionary activities) the Igbo socio-facts and psycho-facts (carriers and containers of the folksmedia) to a new meaning of inferiority. The missionary slogan "Licht ins Dunkel" (light into darkness) underlines this mentality. The consequences of this disposition are the transfer and transplantation of European religious culture and language. The mistake was that the missionary conception presented their missionary image and concern as if they were taking God to Igboland and were less committed that it was God who took them to Igboland. A comment like this presents our argument in this issue:

"What I would like these young men (Missionaries) to know before they embark for Nigeria is that it is God who is taking them to Nigeria not they who are taking God ... When missionaries first came to my country, they spoke of the God who creates the world as if he were a different God from the one we already knew about. We listened and compared what we heard and read in the Bible about this God and discovered that he is the very same God we had already known about. We received many new insights from the missionaries and especially we heard that we could come to know God personally through Jesus Christ. But everyone except the missionaries realised that your God is the same as our God. In other words, our God had brought the missionaries to add to our understanding

51 Catholic Secretariat okigwe: Unpublished report from the ecummenical prayer week for Okigwe, Novenber 1997. 
and commitment. The missionaries had not brought a new God with them. And this is what I would like these young people to realise before they go so that they don't waste so much effort trying to change our ways but devote themselves to building something worthwhile on the foundations that are already there. 52

From the above position, we can now understand why we have acknowledged the "Areopagus" concept not just as a modern insight into the new era of evangelization and the instruments of social communication, but also as the concrete and most superior theological methodology for all cross-cultural missionary commitments and adventures.

Because of this problem of culture-transfer, we notice that most of the church songs are translations and transliterations of European symbolisms (folks-media) lacking African/Igbo rhythms. ${ }^{53}$

The active presence of God in the cosmos is no new teaching to Igbo traditional spirituality. Igbo traditional prayers, rituals and symbols (Ofo, Ogu, Oji, Nzu, Ibiugwu, Onyima, Ikenga, Arusi, Ite-Omumu, Omu, Ogirisi, Omahia etc.) to mention a few attributes of God, myths, legends etc. are indicators of the religious (folks-media) and milieux. ${ }^{54}$

52 Kraft, C., op. cit., p. 10.

53 Mbiti, J., op. cit, p. 299: "Für viele Afrikaner reduziert sich der Sinn der Missionskirche einfach auf eine Reihe von Vorschriften, die einzuhalten sind, auf Versprechungen, die in der zukünftigen Welt eingelöst werden sollen, auf Hymnen ohne Rhythmus, gewisse Rituale und ein paar andere âußerliche Dinge. Dies ist ein Christentum, das sich sechs Tage in der Woche hinter verriegelten Türen verschanzt, um am Sonntag jeweils zwei Stunden lang und dann vielleicht noch einmal in der Woche in Erscheinung zu treten. Das Christentum findet in der Kirche statt, der Rest der Woche geht leer aus. Die Afrikaner, denen auf Grund ihrer Tradition ein religiőses Vakuum fremd ist, finden die religiöse Ausbeute bei dieser Art von Christentum gering, da es nicht ihr ganzes Leben ausfüllt oder ihrem Weltver. ständnis entgegenkommt. Zudem kommen sich afrikanische Christen in Missionskirchen oft vollig deplaziert vor. So gründet z.B. die christliche Lehre zum großen Teil auf Buchern, welche manche ältere Christen nicht zu lesen imstande sind. Die Texte der Kirchenlieder sind Übersetzungen europäischer und amerikanischer Symbole und Weltanschuung; ihre Weisen sind arm an Rhythmus und konnen nicht von Korperbewegungen als religioser Ausdrucksform begleitet werden. Fitr die meisten Afrikaner ist der Gottesdienst in Missionskirchen einfach langweilig. Die unabhängigen Kirchen stellen den Versuch dar, 'einen Ort zu finden, wo man sich heimisch fỉhlt', nicht nur im Rahmen des Gottesdienstes, sondern auch im gesamten Bekenntnis und Ausdruck christlicher Glaubenshaltung. In der Obhut der unabhăngigen Kirchen können die afrikanischen Christen ihren Trănen freien Lauf lassen, ihren Kummer lauthals verkünden, ihre spirituellen und körperlichen Nöte zur Sprache bringen, auf die Welt in der sie leben, eingehen und ihr Inneres vor Gott entbloßen."

54 Uzukwu, E. (1983): Der Spirituelle Gehalt der Igbo-Gebete; in: Mulago Gwa Cikala, 
Bimwenyi-Kweshi highlighted this serious missionary oversight by saying that the cosmos is for an African a narrative theology: "Alle Dinge erzählen von Gott." 55

Because of the above reasons, foreign researchers and theologians have found it difficult to conceive the fundamental concept of the African traditional religion. To this effect, researchers have given this religion all sorts of interpretations. For some this religion is conceived under such concepts as: animism, naturalism, manism, deism, theism, polytheism, monotheism etc. ${ }^{56}$ The dangers within these types of interpretations are that the interpreters do not see the people as they see themselves but rather see them as the interpreters would like to see them. On the grounds of such conceptions, we notice that the mission churches concentrated their activities around the events of conversion to Christianity, care of the sick, schools and education but their was very low interest for the development of a theology. The major institutions like seminaries were copies of European scholastic traditional arrangements. It is suspected that the last synod of African Bishops "Ecclesia in Africa" was bound to have the under-tone "Rome" for this very reason that Africa has not, till present, developed a theology.$^{57}$ And for a process towards such a development, the supervision of Rome became urgent. This could be called a "Baby-Sitter-Syndrome" and was in this respect necessary for the control and moderation of the African theological "Baby-Talk". What we have tried to present in this section can be summed up in the words of Kraft:

"To relate the (gospel) message to the real life of one's hearers, the communicator (missionary) must learn to employ the communication devices (folks-media) familiar to the receptor in ways to which the receptor is responsive. Credible messages start from where the receptor is. In many cultures this involves the knowledge and use of a variety of proverbs, aphorisms, and tales of various kinds. Such literary devices form important vehicles within their communicational system." 58

V. (ed.) Afrikanische Spiritualität und christilicher Glaube: Erfahrungen der Inkulturation, Freiburg, p. 71-92.

55 Bimweny-Kweshi, 0. (1982): Alle Dinge erzählen von Gott: Grundlegung afrikanischer Theologie, Freiburg, p. 83ff.

56 Cf. Idowu, E. (1975): African Traditional Religion: A Definition. New York; cf. Uzukwu, E., op. cit., p. 73.

57 A related issue is the present on-ging symod of Asian Bishops in Rome. It is not a suprise that this synod is asking more autonomy of the local church. cf. Kirche Bunt (53) 3th. Mai 1998, p. 2.

58 Kraft, C., op. cit., p. 161: All in brackets are mine. 


\section{The mission church: the internal problem perspective}

For us to clear the grounds for this section of this paper, we have to note that the missionary zeal to extend the message of Christ to other cultures that are not theirs is a mandate of the good news. This mandate has, "thanks and praise be God", fallen to a large extent into the hands of the locality. The task in the hands of the "locally made Pastors" is the occupation of this section. We want to review how they are made and how the make themselves in the face of this exposition to the doctrines of the good news and their competence and performance in the local pastoral field of the Igbo country.

Pope Pius XII. in his missionary encyclical presented the challenges of this section as follows:

"The church from the beginning down to our time has always followed this wise practice: let not the Gospel on being introduced into any new land, destroy or extinguish whatever its people possess that is naturally good, just or beautiful. For the church, when she calls people to higher culture and a better way of life under the inspiration of the Christian religion, does not act like one who recklessly cuts down and uproots a thriving forest. No. She grafts a good scion upon the wild stock that it may bear a crop of more delicious fruit. " 59

The issues involved in the above statement as they relate to the missionaries from a foreign cultures, have been noted in the above section. But the major implications of this same position, as they may affect the locally made missionaries, present us with diverse problems. We can not in this connection forget the words of Pope Paul VI. to Africa on his historic visit to Uganda in 1969. This statement summarises the direct intention and concern of this section. The Pope started by asking this question: "Must the church be European, Latin, Oriental ... or must she be African?"60

In his answer to this question the Pope says:

"This seems a difficult problem, and in practice may be so indeed. But the solution is rapid, with two replies. First, your Church must be first of all Catholic. That is, it must be entirely founded upon the identical, essential, constitutional patrimony of the self same teaching of Christ, as professed by the authentic and authoritative tradition of the one true Church....

Granted this first reply, however, we now come to the second. The expression, that is, the language and mode of manifesting this one faith, may be manifold; hence, it may be original, suited to the tongue, the style,

59 Pope Pius XII.: Evangelii Praecones, in: The People and the Missions, p. 66-7.

60 Pope Paul VI.: Le Voyage de Paul VI. en Ouganda, 1969, p. 64. 
the character, the genius, and the culture of the one who professes this one faith. From this point of view, a certain pluralism is not only legitimate, but desirable. An adaptation of the Christian life in the fields of pastoral, ritual, didactic and spiritual activities is not only possible; it is even favoured by the Church. The liturgical renewal is a living example of this. And in this sense you may, and you must, have an African Christianity. Indeed you possess human values and characteristic forms of culture which can rise up to perfection such as to find in Christianity, and for Christianity, a true superior fullness, and prove to be capable of a richness of expression all their own, and genuinely African. ...It will require that your African soul 'become imbued to its depths with the secret charisms of Christianity, so that these charisms may then overflow freely, in beauty and wisdom, in the true African manner." 61

What the Pope has stated above are the conditions for an authentic missionary practise. In a missionary method of this nature, the local language, the style, character, genius and suited tongue are prerequisites for an authentic evangelization. These conditions are the intrinsic com. ponents of the folks-media.

When we consider the fact that oracular media make up over $80 \%$ of the present information dissemination system of the present Igbo country, it is therefore no over-statement to say that the folks-media enjoy the richest information currency alongside electronic and written media.

The most serious concern now is to find out the extent of competence and performance of the local missionary in the face of the oracular media with respect to the said folks-media.

The most serious local and or internal problem faced by the mission of evangelization and the methodology in Igboland today, is imbued in the nature of the linguistic and language landscape of Nigeria. The MacBride-report ${ }^{62}$ of 1980 recorded about 28 principal languages being spoken in Europe, about 23 in South Asia, the Former USSR had 89, Africa has 1250 languages while Nigeria alone has about 395 languages ${ }^{63}$ including Igbo - our concern in this paper. Because of this linguistic heterogenicity it becomes naturally difficult for a country like Nigeria to develop a lan. guage policy in the face of such linguistic diversity. This difficulty has been identified by Elugbe as follows:

"Since ethnic divisions are often along linguistic lines, it is assumed

61 Mid., p. 64-6.

62 MacBride, S. (1980): Many Voices One World. Communication Society Today and Tomorrow, Paris, p. 49.

63 Braimoh, D. (1982): Communication Strategies for Effective Literacy Compaign in Nigeria, in: Nigeria Magazine, No 145, p. 26. 
that the existence of many languages means the existence of many basically antagonistic ethnic nationalities trying to form a Nation. ... Language is one of the, if not most enduring artefacts of culture. Unless forced by conquest or by superior numbers or by socio-economic and political domination to give up their language, a people can always have their history traced through their language." 64

The Igbo language is only a regional official language in the face of other languages of Nigeria. The natural impediment created by this type of linguistic and language landscape is the issues of tension between Nationism and Nationalism. ${ }^{66}$ In an attempt to overcome this debacle English - 'a colonial Language' has become triumphant. This ex-colonial and Missionary language has become almost the "First" language in most Igbo homes especially in the homes of the so-called 'milieux dirigeants' creating a linguistic and language platform of an elitist opportunism whereby the English competence and performance underlines an attitudinal pride and superiority feelings within the Igbo social order. This situation is what I have called the 'literate-illiteracy' and 'language suspension' situation. ${ }^{67}$ Most of the University Graduates including the Graduates from Major Seminaries and Religious Institutions are more at home with the English language and the due symbolisms than the Igbo - their Mother Tongue. It is still common practice that an admission to any graduate education (including the major Seminaries) is conditioned on a creditpass in English language and not on the local language/s. We have to re-emphasise that all languages are equal in dignity and are 'tools' for the expansion of one's consciousness within his or her 'real world' with respect to the socio- religious, individual, group-behaviour and identity. We have to remark, that it is even an act of a 'religious modern trend' to preach and chant in English instead of making use of the language of the 'common' person which, in this regard, stands to be the Igbo language and the folks-media symbolism, as we have shown in the diagram above. We cannot neglect the fact, as we have said above, that language symbolism gives weight and meaning to the ideal medium of communication and the real world of the locality. Symbols (with regard to the analytic contents of the folks-media) are small books of the people's history and tradition. Within this content analysis of the symbols and language, one

64 Elugbe, B. (1990): National Language and National Development, in: Emenanjo, E. (ed.), Multilingualism, Minority Languages and Language Policy in Nigeria, p. 11.

65 Roger, B. (1976): Sociolinguistics: Goals, Approaches and Problems, London, p. 169 ff.

66 Okonkwo, J. (1994): Nationalism and Nationism: The Sociolinguistic Cross-Roads of the Nigerian National Language Policy, in: AAP 40 (1994): 115-130. 
can have adequate knowledge of the people. To know a people means to know their language and symbolism. When a pastor lacks this competence and the performance in the language and the co-efficient symbolism, the effect would be what Ukah presented as follows: "The trouble with most sermons is that they give answers to questions that people are not asking." 68

Despite the fact that the Igbo culture and society were among those within the African continent that were fractured by cross-cultural effects of colonialism and Christianity, it is more sad that the Igbo themselves add more fracture to their socio-cultural members by their fast-line assimilation of European 'habitus'.

"The fact, however, remains that whatever the cause the Igbo, more than many other Nigerian people, tended to abandon their indigenous culture for European culture rather recklessly. In fact so eager were the Igbo to embrace the new ways at the expense of their indigenous culture that many Europeans who worked in Igboland became worried about it."

On this ground, the Igbo themselves assisted the missions in destroying their own fabrics and the result is that the present missionary ventures on the local hands and levels are, to a large extent, still building on the ashes thereof. ${ }^{70}$

The Chameleon, according to an Igbo proverb, says that it would never abandon the dignified and worthy slow-march of its ancestors just because the ecology is on fire. If this statement stand to be true for the Igbo mentifacts, sociofacts and philosophy, one would therefore expect the local Igbo Pastors to become more critical and eclectic over their cultural experience - past and present - in their entirety, selecting and reactivating those ideas, institutions and practices capable of serving the purposes of this new era of evangelization..$^{71}$

\section{Conclusion}

The church in this present era can no longer think of any process of evangelization without deep concern, understanding and appreciation of the so-called "Signs of the time". For "Die Sache Jesu" to gain grounds as

67 Ibid., p. 124.

68 Ukah, L. (1994): The Priest as an 'Effective Communicator', in: Okonkwo, J. (ed.) Pastoral Management and Communication, Enugu, p. 36.

69 Afigbo, A. (1977): Towards a Cultural Revival Among the Igbo-Speaking Peoples, in: Ogbalu, F. et. al (ed.): Igbo Language and Culture-Vol. II, Ibadan, p. 4.

70 Ibid., p. 5.

71 Ibid, p. 10. 
"Glaubensvollzug", the issues of "Church in Context" must be presented as the "conditio" for the propagation of the good news. The implications of the 'locality of the Church' after the 2. Vat. Council demands that the good news of Christ should have meaning for and in the culture and society of the people and help them in their transformation towards the higher values of Christian principles of salvation. Franz-Josef Eilers says to this effect as follows:

"Kirche im Kontext ... Christliche Botschaft befindet und entfaltet sich immer im bestimmten Kontext einer örtlichen und sachlichen Umgebung. Sie ist eingebunden in menschliches Leben, in die Kultur menschlicher Gesellschaft, wenn sie zur Inkarnation werden soll." 73

This is precisely the occupation of "Inculturation". 74 Faith in this context must have a "situated usage" in order to give meaning and answer to the questions of the incumbent people and their real world. This real world it the people's symbolic world.

Eilers supports this position by stating that "das Evangelium müsse die Kultur und die ganze Lebensart der Menschen befruchten " ${ }^{75}$

What we have stressed here is that there can never be a culture-free Christianity. Christianity will be "logically odd" 76 if it does not speak the "public language". This so-called "public language" demands that the pastor (missionary/foreign or local) is expected, as a condition for the propagation of faith, to attach the "feelings" of the community and their common social counters and or tags to the mission of the good news. This will help maximise the solidarity of social relationship in communicative structures and the transcendental mandate of salvation. Evangelization in this new era means in our context the extension of the logos to the whole universe of the listener. In this connection, the good news will stand as a process of "self-involvement" 77 and "self-committing - logos competence and performance". ${ }^{78}$ This is what Ramsey calls "the whole job of living the gospel". 79

Metz, J. B. (1973): Kleine Apologie des Erzählens, in: Concilium 9 (334-339);

Weinrich, H. (1973): Narrative Theologie, in: Concilium 9 (329-334).

73 Eilers, F.-J. (1997): Kirche und Interkulturelle Kommunikation, in: Communicatio Socialis (30. Jg.) Heft 2, p. 94.

74 We consequently left out this concept for the very fact that much has been said on this. Our interest is to express the practical possibilities of this conception.

75 Ibid., p. 97.

76 Ramsey, R. (1969): Religious Language: An Empirical Placing of Theological Phrases, London, pp. 49, 91.

77 Cf. High, D. (1967): Language, Person and Belief, New York, p. $167 \mathrm{ff}$.

78 Cf. Mananzan, M. (1974): The Language Game of Confessein One's Belief, Tübingen, p. 229.

79 Ramey, R., op. cit., p. 37. 
We would like to conclude this paper by citing Kraft who was once a missionary in Nigeria. He opts for propagation of the gospel message as a "kenosis" and or incarnated folks-media credibility. He said once as follows:

"How sad it was for me recently to hear a whole sermon by an African pastor in the Hausa (Nigerian) language without a single proverb, cultural aphorism, or even an illustration in it. And this in a language and culture that in ordinary conversation drives virtually every point home with at least one proverb. But this man had been taught to 'preach from the Bible' not from life. "80

This position gains a common appreciation in the Igbo mission and language also. When, therefore, the folks-media are "Mmanu Okwu Chukwu" 81 for the African Christian communities, we would appeal to the Church authorities, beginning from Vatican to the local church communities, to express this urgency in the most concerned manner of importance and place their equality in function and service of the gospel-spread to those of the electronic and print media.

80 Kraft, C., op. cit., p. 161.

81 "Lubricants for the words of the gospel-preaching an spread" - Sitz im Leben. 